\title{
The Constitution Act, 1982: the Foreseen and Unforeseen
}

\section{Hon. Barry L. Strayer, Q.C.}

“... not exactly what we had in mind."

\section{Introduction}

I started preparations for my first constitutional conference in an office overlooking Wascana Lake nearly forty-seven years ago. I was a young lawyer in the Department of the Attorney General of Saskatchewan. Prime Minister Diefenbaker had announced that there would be a Conference of Attorneys-General in early October 1960, chaired by Justice Minister Fulton, to seek agreement on "Repatriation of the Constitution." As I expressed interest in the conference to the Attorney General, and had recently taught constitutional law for a year at the University of Saskatchewan, I was made the secretary of the Saskatchewan delegation. This involved most of the work of research and writing position papers and speeches. But it also involved making hotel and travel reservations for which I claimed no particular skill! Of course, after four such meetings in 1960 and 1961 we reached no agreement on repatriation, but it gave me on the job training in constitutional reform.

A few years later, when I was teaching full time at the College of Law in Saskatoon and doing some writing in the constitutional field, I was invited to go to Ottawa to help develop a position for the Government of Canada on constitutional reform. My first period there was during the summer of 1967 when I was assigned to advise the new Minister of Justice, Pierre El- liott Trudeau. He asked me to develop a position paper on a constitutional bill of rights, initially for use by Cabinet, and then to be elaborated into a discussion paper in aid of negotiation with the provinces for the adoption of a Charter of Rights. The end product, with some modifications, was indeed published in a 1968 position paper. ${ }^{1}$ In that year I went back to Ottawa on a full-time basis, eventually resigning my university post and joining the public service. First in the Privy Council Office, and later as Assistant Deputy Minister of Justice, I was heavily engaged in the constitutional discussions which went on intermittently for fourteen years, and which resulted in the Constitution Act, 1982. ${ }^{2}$ I guess it is for this reason that I have been asked to address which of the developments under this Act in the last twenty-five years were foreseen and which were unforeseen.

I have chosen three areas which I regard as the most important elements of the 1982 constitutional amendments: namely patriation, the Canadian Charter of Rights and Freedoms, ${ }^{3}$ and the constitutionalization of Aboriginal and treaty rights. In this article I adopt the analytical framework of that great philosopher Donald Rumsfeld, former Secretary of Defence in the Bush administration, who said of the war in Iraq: There are some things we know we know, some things we know we don't know, and some things we don't know we don't know. ${ }^{4}$ This was indeed our position regarding our knowledge of the future in launching these constitutional reforms. 


\section{Patriation}

The term "patriation" is shorthand for the process of transferring to Canada the legal control of its own Constitution. As is well known, when our Constitution was originally enacted by the British Parliament in 1867 as the British North America Act, 1867,5 it made no provision for Canadians themselves to amend it in future: it was, like any other British statute, amendable by Westminster alone. This accorded with the colonial nature of our status as a country, albeit the 1867 Constitution gave us most of the elements of self-government. In our first few decades as a Dominion little thought was given to the fact that we had to rely on the British to pass laws for Canada in respect of our constitutional arrangements. Over time attitudes changed. When Australia was federated by Act of the British Parliament in $1900,{ }^{6}$ she was given the power to amend her Constitution; this accentuated the problem of our own continuing dependence on the Mother of Parliaments. More importantly, in the opening decades of the twentieth century, particularly after Canada's distinguished role in the First World War, there was in this country a growing sense of Canadian nationhood. Indeed, after the Great War Britain realized that her senior Dominions, including Canada, had to be recognised as fully autonomous states. This position was agreed to at the Imperial Conference of 1926. The result was the enactment of the Statute of Westminster, 1931, ${ }^{7}$ which recognized this position and stated that the British Parliament would no longer legislate for the Dominions. However, an exception had to be made for Canada in respect of amendments to our Constitution. This was at Canada's request, and that request was made because we could not agree among ourselves as to how we would amend our Constitution if the British didn't do it for us. The federal government, eager to enhance national sovereignty, had been trying since 1920 to get agreement on a domestic amending formula. The basic issue was always the same: under an all-Canadian amending formula, how many provinces would have to agree with the federal government or Parliament before proceeding with an amendment to the Constitution?
This debate continued periodically for the next sixty years in numerous federal-provincial conferences at which agreement was never reached on an amending formula. The last of these meetings occurred in September 1980 and it too failed. At that point, the federal government, led by Pierre Trudeau, introduced a resolution in Parliament which requested the Queen to place before Westminster a request to adopt an amending formula for Canada and thus sign off on any future legislative power over Canada. This initiative was condemned ultimately by eight of the ten provinces, the so-called Gang of Eight, because they had not been consulted on the content of the resolution. Three of these eight provinces (Manitoba, Newfoundland and Quebec) initiated court proceedings in the form of reference questions in their respective courts of appeal, with the full knowledge that the questions would end up in the Supreme Court of Canada. The references asked if it was legally correct for the federal government to seek and obtain a constitutional amendment from Westminster in the fashion that it did. The Supreme Court ultimately said that it was legally correct in proceeding unilaterally. The three provinces also asked if such a procedure was in accordance with the conventions of the constitution: that is, was federal unilateralism consistent with accepted past practices? Seven provinces in the Gang of Eight contended that no such amendment could be made in accordance with constitutional convention without unanimous provincial consent. To this the Supreme Court replied that while unanimous consent was not required there must be, by convention or practice, a "sufficient measure of provincial consent," of which there was not here. Only Ontario and New Brunswick supported the federal initiative. ${ }^{8}$ Not satisfied with this, Quebec initiated an additional reference question arguing that even if the agreement of every province was not required, by past practice and fundamental principle at least the consent of Quebec was always required. The Supreme Court heard and rejected this argument. ${ }^{9}$

After the Patriation Reference, in which the Supreme Court said that not unanimity but rather a "sufficient measure of provincial consent"10 was necessary to bring about the constitutional 
changes contained in the federal proposal, there was a further Federal-Provincial Conference in November 1981 to seek that sufficient measure of agreement on an amending formula, the adoption of a Charter of Rights, and a few other changes. Eventually all governments but Quebec came to agreement. The changes agreed upon by the ten governments were adopted in a Joint Resolution of Parliament which was forwarded to Westminster where it was adopted in March 1982, as the Constitution Act, 1982.

What the Government of Canada, as the national government with primary responsibility for national sovereignty, had sought for some sixty years was the completion of our legislative autonomy, a hallmark of a sovereign state. It sought to do this in a way which would be regarded as legitimate: in accordance with legal requirements, but also with politically accepted practices. What the federal government and the nine provinces which endorsed the 1981 Accord leading to the Constitution Act, 1982 expected was that if they proceeded in accordance with the decision of the Supreme Court requiring not unanimity but rather a "sufficient measure of provincial consent" to change our Constitution, the resulting changes would be viewed as legitimate by all Canadians. They naturally believed that the support of nine of the ten provinces was "sufficient" if, as the Supreme Court had said, unanimity was not required. That is what was foreseen in respect of patriation. Yet things did not work out that way. Many residents of Quebec, and some of their supporters outside that province, continue to believe that Quebec was "humiliated" by this process whereby changes were made without her consent. They go even further and suggest that "Quebec is not in the Constitution" because the separatist government and a majority in the Quebec legislature opposed those changes in 1981.

It may first be observed that other voices of Quebec did support the Constitution Act, 1982. Of Quebec's seventy-five Members of Parliament, seventy-one voted for the Joint Resolution adopting the Act. And a public opinion poll taken in May 1982 showed that 49 percent of the people in Quebec approved of the Joint Resolution, with only 16 percent opposing it. ${ }^{11}$ (In a recent poll, residents of Quebec proved to be the most supportive of the Charter after twenty-five years; in fact, 61 percent, a higher percentage than in any other province, rated the Charter's impact as positive or very positive. ${ }^{12}$ This suggests that residents of Quebec believe that this part of the 1982 Constitution applies in Quebec, and that they harbour few feelings of "humiliation" about the process that brought it to fruition.) Second, and more importantly, patriation was effected by a procedure approved by the body to which Quebec had on two occasions willingly submitted questions as to whether her consent was essential for any such amendment. Twice the Supreme Court said no. It must be remembered that it was not the Government of Canada which chose that forum to determine the political legitimacy of its amendment proposal, that is to say, to determine the nature of any constitutional conventions governing the practice of achieving constitutional amendment. Indeed the Government of Canada in the Patriation Reference objected to the Supreme Court pronouncing on constitutional conventions on the basis that this really involved a political question - an issue of acceptable political conduct. Yet once the Supreme Court did so pronounce, at the insistence of Quebec, Ottawa and the other nine provinces followed these instructions as to the character of acceptable political practice. If Quebec was humiliated, it was on her own government's initiative.

That being said, it is one of the major disappointments following the adoption of the Constitution Act, 1982 that it has not brought the stability and dignity to our national sovereignty that we expected, and were entitled to expect. Legally, of course, patriation worked. Westminster can no longer make our laws for us. All laws governing Canada are made in Canada. Should we ever, by some chance, happen to agree on a significant constitutional amendment we could make it ourselves. But the political legitimacy of the Constitution Act, 1982 continues to be disputed by Quebec nationalists and their sympathizers, both within and outside that province, and we have gone through periodic disturbances such as the Meech Lake ${ }^{13}$ and Charlottetown Accords, ${ }^{14}$ the 1995 Quebec secession referendum, and most recently the resolution in the House 
of Commons recognising the "Québécois" as a nation. ${ }^{15}$ What we had foreseen as a major confirmation of our maturity as a sovereign state remains a source of disunity. We didn't know we didn't know this.

\section{The Charter}

I should begin by affirming my belief that the Charter has largely met the expectations of its framers and must be adjudged a success. I should also affirm that we recognized that the general language necessarily used in an enduring constitutional instrument to describe the protected rights and freedoms meant we knew we didn't know all of its potential applications. This has proven to be true, but for the most part I believe these interpretations have been beneficial and within the anticipated range of outcomes we expected. I will, however, now describe some outcomes which were not expected and which in my view go beyond the social consensus which brought about the Charter.

A consensus for a constitutional bill of rights, although advocated by Pierre Trudeau as Minister of Justice and pressed by him as Prime Minister, was slow to develop. From 1968 when it was first discussed at a Federal-Provincial Conference, down to 1980 when Ontario and New Brunswick got behind it, it had no provincial backing. The other eight provinces opposed its adoption until November 1981 when the federal and nine provincial governments reached agreement on an Accord to seek the amendments finally adopted in the Constitution Act, 1982.

Traditionally, Canadian politicians and officials were opposed to a constitutional bill of rights or any international commitment that would interfere with parliamentary supremacy. In particular they could not accept the idea of Parliament or the legislatures being ordered by a court to spend money. When Parliament studied the United Nations' Universal Declaration of Human Rights ${ }^{16}$ of 1948 there was hesitation in endorsing it because it contained rights to social security, employment, education, and other economic rights - all things that would cost money and so were, in the eyes of legislators, matters to be provided by legislation in accordance with the judgment of elected representatives. Members of all political parties opposed the notion of legally vested rights to employment, social security, etc. Parliament approved the accession by Canada to the Declaration only on the assumption that we were merely accepting an obligation to promote such objectives. ${ }^{17}$ The first head of any government to advocate a constitutional bill of rights was Premier T. C. Douglas of Saskatchewan who proposed the idea at a Federal-Provincial Conference in Quebec City in 1950. No other government supported the idea at that time. The federal Liberal Party only began to advocate a constitutional bill of rights in opposition to Mr. Diefenbaker's statutory Canadian Bill of Rights ${ }^{18}$ when it was under debate in Parliament in 1960. The subject was not formally put on the agenda of any federal-provincial meeting until the Constitutional Conference of 1968. This is all to demonstrate that, historically, politicians were reluctant to give to the courts the power to make social policy.

Indeed, it is fair to say that the concept of a constitutional bill of rights was that of a protector of "negative rights" - that is, a protector of citizens' liberty and freedom of choice from the interference of government. Political, legal, mobility, and equality rights were to be guaranteed free of state restraint. What was not contemplated was that the Charter would become a road map for social entitlement programs designed and enforced by the courts.

Yet the courts, led by the Supreme Court, have found ways to dictate laws and determine social programs in ways partly foreseeable but mostly unforeseen. In at least one respect this has come about by changes made to the draft Charter in its latter stages of development during the work of the Special Joint Committee of the Senate and House of Commons on the Constitution of Canada in its meetings of 1980-81. Mainly as the result of submissions by feminist groups, the original proposed formulation of the guarantee in section 15 of "equality before the law and equal protection of the law" was enlarged to equality "before and under the law and ... the right to equal protection and equal benefit of the law ..."19 The addition of various prep- 
ositions and nouns meant that the Charter did give the courts a potential power to pronounce on the adequacy of entitlements to social programs for certain deprived groups. What remedy they might give was not prescribed. I think we assumed that courts would, in the exercise of their powers under section 52 of the Constitution Act, $1982,{ }^{20}$ at most pronounce statutes invalid if found to be discriminatory because of a lack of equality in the benefits they provided, and leave it for Parliament or the legislatures to re-enact them in a form which, while providing for equal benefits, would correspond to the legislative bodies' priorities and spending capacity. Or, if the courts resorted to their powers under section $24,{ }^{21}$ they would not think it "appropriate and just in the circumstances" to go beyond a declaration that the offending action or inaction by government is invalid. Again, we assumed that courts would leave it to Parliament and the legislatures to correct unconstitutional statutes to the extent they thought possible and appropriate.

It didn't work out that way. In an early Charter case, Schachter $v$. Canada, ${ }^{22}$ the Supreme Court held that where a statute gives benefits to certain persons but not to others similarly situated, it was open to the courts to find the law not only invalid as it stood under section 52 , but also to "read in" to the statute the provision of similar benefits to the deprived class of persons. In effect, the Court said it could legislate for Parliament rather than simply declare that the law makes an invalid distinction, suspend the declaration, and then let Parliament take such remedial measures as it thought consistent with the parameters identified by the judiciary. ${ }^{23}$ In Eldridge v. British Columbia, ${ }^{24}$ however, it was not the validity of a statute that was at issue, but rather the adequacy of administrative action under section 15 of the Charter. The Court responded with a subsection 24(1) remedy to require that medical services provided under a provincial medical insurance program include sign language interpretation for deaf patients. Again, this was a problem of ensuring "equal benefit" of the medical insurance law and it was the Court which decided what services should be provided at public expense.
Admittedly, the Court has shown some reluctance in recent times to order the expenditure of money by legislatures to ensure "equal benefit" of the law, or for other purposes. ${ }^{25}$ But I understand these cases to have turned on other principles and do not represent an abandonment of the Court's willingness to order the provision of specific services and hence the expenditure of public funds.

Not only have the courts amended legislation for the purpose of providing services and spending funds not voted upon by legislatures, but they have also amended laws to regulate matters which legislative bodies have preferred to leave unregulated. A salient example may be found in the Supreme Court's decision in $V r$ iend v. Alberta. ${ }^{26}$ There a homosexual teacher at a private college in Alberta was dismissed because of his sexual orientation. The provincial law prohibiting discriminatory employment practices did not include sexual orientation as a prohibited ground. The legislative history made clear that this had been a deliberate omission by the government and legislature. It was ultimately held by the Supreme Court that the failure of the legislature to prohibit discrimination on grounds of sexual orientation was itself discriminatory, and the Court read into the legislation the necessary prohibition which the legislature had chosen not to include. The Supreme Court simply could not contemplate the legislature being neutral on this issue. Not only must Alberta's legislature refrain from evil, it must also do good. One anomalous consequence of this is that, although we understood the Charter to be for the control of the state and not of individuals, the Court here used it to enact a prohibition on the actions of all private employers in Alberta. ${ }^{27}$

Those who drafted and agreed to the terms of the Charter, be it federal or provincial politicians or officials, had another major surprise in Re B.C. Motor Vehicle Act ${ }^{28}$ where the Supreme Court interpreted section $7^{29}$ to be a mandate for the courts to ignore laws which, though otherwise constitutional, they consider unjust. That section, of course, guarantees the right to "life, liberty and security of the person and the right not to be deprived thereof except in the 
accordance with the principles of fundamental justice." In lieu of "principles of fundamental justice," earlier drafts had used the term "due process." The record is abundantly clear that no one wanted that term used in the Charter because it had been interpreted, in the United States, to include what is called "substantive" due process: that is, it was interpreted to allow the courts to second-guess legislatures by striking down a law, even if it were otherwise constitutionally unobjectionable, because it embraced a bad policy of which the courts did not approve.

At one time, socially progressive legislation had been struck down by the U.S. Supreme Court as contrary to substantive due process. The Canadian framers did not want such a result here. We therefore employed the words "principles of fundamental justice" which were found in the Canadian Bill of Rights and which had been interpreted by the Supreme Court in 1972 to refer to procedural requirements only. ${ }^{30}$ Admittedly the context was different in that statute, and had we enjoyed the luxury of more time we probably would have employed more precise language. In fact, we did consider the suggested alternative of "natural justice" at that time, but rejected that traditional term because its use was still restricted to judicial and quasijudicial proceedings. If there were an ambiguity in the term "principles of fundamental justice," it would not have taken much effort on the part of the Court, which, we are frequently told, is always in pursuit of "purposive" interpretations of our constitutional instruments, to learn from the public record what was the purpose of the elected representatives who conferred on courts the mandate to apply the Charter, but who also determined the language to which the judiciary was expected to give its intended effect. If, as we are told by the Court, this phrase gives the judiciary the mandate to apply the "basic tenets of our legal system" in determining whether a law complies with "fundamental justice" in a substantive sense, a superficial examination of that legal system would have revealed that it has never been part of our constitutional or common law heritage that judges be free to refuse to apply plainly worded statutes not otherwise in conflict with the Constitution, just because they didn't approve of the policy implemented by that statute.

One would, I think, have to go back to Lord Coke's pronouncement in Dr. Bonham's Case $e^{31}$ in the seventeenth century to find in English or Canadian law such a judicial claim to exercise legislative power, and Coke's notion, never widely received (certainly not in Canada), barely survived that century. ${ }^{32}$ In 1985 , however, only three years after the adoption of the Charter "by the elected representatives of the people of Canada" (as the Supreme Court piously reminded us in Motor Vehicle 33 ), the Court found those representatives to have intended the adoption of the test of substantive due process by their use of the phrase "principles of fundamental justice." While I believe in the "living tree doctrine" 34 by which the meaning of the Constitution may change over time with the changing society which it must serve, just three years growth of that living tree could hardly produce such fecundity! Had our society evolved so profoundly between 1982 and 1985 that we had already come, and for the first time, to accept the supremacy of the courts in determining, not just the constitutionality, but the policy of statutes?

While the impact of this holding has so far been somewhat limited, we have recently been reminded of its potential use as authority for the courts actively to manage social policy. In the case of Chaouilli v. Quebec, ${ }^{35}$ decided by the Supreme Court of Canada in 2005, a majority of the panel held that the policy of a provincial law to prohibit the purchase or sale of private medical insurance was wrong, and therefore unconstitutional. Three of the majority of four judges based their decision on "the principles of fundamental justice" in section 7 of the Charter. All four of that majority also invoked section 1 of the Quebec Charter of Human Rights and Freedoms, ${ }^{36}$ which is believed to have magic qualities similar to those of section 7 of the Charter. Thus, the Court settled a long and highly contested issue in Canadian public policy as to whether it is fair and just to deny certain fortunate people, who can afford private insurance and who do not suffer from disabilities that would make them uninsurable, the right to have the faster and arguably better care that would 
be provided through private insurance. So far, through many elections and changes of parties in power, elected representatives have not been prepared to allow this, mainly on the basis that it is contrary to egalitarian principles (arguably even against section 15 of the Charter), but also because it would have the effect of weakening the public insurance system by drawing away resources to give better and faster service to the more fortunate privately insured. Is it right that in spite of all this, the courts are in a better position than elected governments to determine what is a just distribution of medical services?

I will not belabour the point or get further into the minutiae of Charter interpretation. These are some of the most important unforeseen and I think unforeseeable of its interpretations.

\section{Aboriginal Rights}

The other change of great importance effected by the Constitution Act, 1982 was the addition of section $35 .{ }^{37}$ As ultimately enacted it includes the following subsections:

35. (1) The existing aboriginal and treaty rights of the aboriginal peoples of Canada are hereby recognized and affirmed.

(2) In this Act, "aboriginal peoples of Canada" includes the Indian, Inuit and Métis peoples of Canada.

(3) For greater certainty, in subsection (1) "treaty rights" includes rights that now exist by way of land claims agreements or may be so acquired.

There was no such provision in the draft resolution tabled by the federal government in Parliament in October 1980 as its constitutional proposal. I can recall no discussion of this within the government prior to that time, nor during the previous twelve years of intermittent federal-provincial discussions on constitutional reform. However, once a text of patriation legislation was up for discussion in the Joint Parliamentary Committee, representations were received from many quarters: 104 groups and individuals appeared as witnesses and some
1,200 written representations were received by the Committee. Among those appearing and making forceful presentations were several representatives of Aboriginal peoples. They pressed for constitutional recognition and protection of the type effected in section 35 . Their proposals received particularly strong support from members of the federal New Democratic Party (NDP) caucus. Prime Minister Trudeau, given the many forces of opposition to the federal proposals then abroad in the land (including the governments of eight provinces), was anxious to have the support in Parliament of the NDP to complete patriation. I and some other federal advisers were closeted from time to time with Ed Broadbent, the then NDP leader, and his advisers to try to work out a suitable text. The one agreed upon was similar to the text which was finally adopted, and seemed to me to be a very strong endorsement of, and protection for, $\mathrm{Ab}$ original rights. Indeed, I had to advise federal ministers that, if they were to entrench in the Constitution something along the lines being discussed, we could not give much meaningful advice as to how it would be interpreted by the courts. I will return in a moment to the causes of our uncertainty.

The text, essentially as mentioned above in subsections 35(1) and (2) (the word "existing" was not then included in subsection 35(1)), was approved by the Committee on 13 February 1981 and was transmitted to Parliament where it was approved by both Houses without change on 23-24 April 1981. There then followed a hiatus during which we argued before the Supreme Court in the hearing of the Patriation Reference, ${ }^{38}$ and awaited the results. When the Court pronounced, in effect, that we had not achieved "a sufficient measure" of provincial support, a further First Ministers Conference was held in early November 1981. There the Accord was reached whereby nine premiers (all but Quebec's) and the prime minister agreed on a text of constitutional changes. As a result of the objections, at that time, of several premiers to the inclusion of section 35, it was not included as part of the Accord. But once the Accord was made public, this omission attracted much criticism, and not just from Aboriginal peoples. Eventually, the reluctant premiers agreed to its 
restoration, mainly on condition of the addition of the word "existing" to subsection 35(1). As I recall it, subsection (3) was added at the urging of Aboriginal leaders to ensure that recently negotiated and future land claims agreement would have the same entrenched protection as the traditional treaties referred to in subsection 35(1). With these changes, and some others, the package was endorsed by Parliament and sent to Westminster where it was enacted as the Constitution Act, 1982.

I return then to my focus on the foreseen and unforeseen. Speaking, I think, for many participants in the framing process, I have to say that we considered the outcome of section 35 to be largely unforeseeable. This was one area where we knew we didn't know. For this reason I would characterise its interpretation to date as unforeseen. This is not to denigrate the generally good job which I think the courts have done in putting meat on these bare bones. To appreciate the value of what has been done, I need to go back to the sources of our uncertainty - to show just what a difficult task was left to the courts. Following are major areas of uncertainty apparent to us in 1982 .

1. What rights would be protected? We were fairly certain as to what "treaty rights" and rights under "land claims agreements" were, as these are, by definition, reduced to writing. Even there, the language of some of the old treaties is full of ambiguities and generalities. But what did "existing aboriginal rights" embrace? In 1982, we thought we understood Aboriginal title to land, one form of Aboriginal rights. Indeed, by this time the dissenting reasons of Justices Hall, Spence, and Laskin in Calder v. British Columbia ${ }^{39}$ had been accepted, at least in Ottawa, as the correct view of Aboriginal title. This was a view of title based on occupancy and use by an identifiable group of Indians prior to the Crown asserting sovereignty over the lands. So established, title entitled a group to exclusive continuing occupancy unless it had been extinguished by the agreement of the relevant group, or by a deliberate act of the competent government. This view was confirmed by Delgamuukw v. British Columbia, ${ }^{40}$ the leading $1997 \mathrm{Su}-$ preme Court decision under section 35. There were, perhaps, at least two surprises in that decision. One was that, as Aboriginal title is not based on the practices, customs, and traditions of the claimants (as are other Aboriginal rights), title is not confined to traditional uses of the land. Thus, Aboriginal title includes mineral rights even if their ancestors never exploited them. ${ }^{41}$ (This I found surprising as, in my understanding, the claim to Aboriginal title depended on traditional occupation of the land and this occupation was essentially surface occupation.) Another doubtful matter, clarified in that case, was the weight to be given to evidence proffered by claimants in the form of oral history.

2. As I say, while we knew the likely parameters of Aboriginal title, we were quite uncertain as to the identification of other forms of $\mathrm{Ab}$ original rights. Indeed, the Supreme Court has developed criteria for this purpose. Such a right must be based on a practice or custom of the claimants' ancestors, employed before the time of first contact with Europeans. It must have involved a use of land, but not necessarily land for which the claimants could assert Aboriginal title. The practice or custom must be shown to be distinctive of their culture, one which makes the culture what it is. ${ }^{42}$ Thus, some important markers have been established for defining the scope of the guarantee of "aboriginal rights" other than Aboriginal title, matters heretofore not given much attention in the jurisprudence.

3. We were not completely certain what the legal effect of the "recognition" and "affirmation" of Aboriginal rights would be since this section was not part of the Charter, section 1 of which "guarantees" 43 the rights set out in it. But the courts soon confirmed that, provided such rights were still "existing" as of 17 April 1982, they could no longer be extinguished or severely impaired by governmental action. This stands in contrast to the situation before 1982 when Aboriginal land rights, at least, could be extinguished by federal executive or legislative acts as 
long as a clear intention was shown to effect such extinguishment. Of course, both before and after 1982, such rights could be extinguished with the agreement of the Aboriginal community: this was normally a key element of the treaties, and was usually an element in lands claims agreements.

4. Also, because section 35 is not part of the Charter, the rights entrenched in it are not subject to the provisions of section 1, which permits "reasonable limits" to Charter rights if such limits are "prescribed by law [and] can be demonstrably justified in a free and democratic society." Nevertheless the courts have recognized, in effect, that Aboriginal rights can be similarly limited if there is a valid legislative object for the limitation, if it involves only as much infringement as is necessary, and if in the nature of an expropriation it provides for compensation and is the subject of consultation with the rightsholder group. Further, such control must be consistent with the federal Crown's fiduciary duties to the holders of the rights. ${ }^{44}$ An obvious example of permissible limits is a conservation law applied to the exercise of Aboriginal fishing rights. ${ }^{45}$

5. In 1982, we could only speculate as to whether section 35 would guarantee an Aboriginal right of self-government, a right which had been often asserted but not clearly recognized. In Delgamuukw $w^{46}$ the Supreme Court drew back from deciding that issue, it being thought unnecessary to dispose of the case. As far as I am aware, it has otherwise been given only limited recognition. ${ }^{47}$

6. We also had to admit in 1982 that we could not provide any meaningful definition of the term "Métis" as used in section 35. Section 91(24) of the Constitution Act, $1867^{48}$ assigns to Parliament jurisdiction over "Indians and lands reserved for the Indians." An elaborate legislative scheme identifies who are "Indians" for purposes of the exercise of this power. The Supreme Court assisted in the definition of the federal power years ago ${ }^{49}$ by holding that Inuit are "Indians" - which may have been a surprise to both groups! But we had no legal guideposts as to who is a "Métis," a group designated in section 35 as having specially guaranteed rights. In various contexts in the past, governments had been content for persons of mixed Aboriginal and European blood to identify themselves as either Indian or Métis, usually dependent on which community accepted them as members. The Supreme Court tackled this difficult question in R. v. Powley. ${ }^{50}$ There a group sought to establish a site-specific Aboriginal hunting right. The Court recognized them as Métis. The indicia adopted by the Court were that the claimants be of mixed ancestry, live in an identifiable Métis community, and have developed their own way of life distinct from both Indians and Europeans, with practices that were site-specific and with a sufficient degree of continuity. Such groups would have commenced to exist (obviously) after the arrival of Europeans but must have "evolved and flourished prior to the entrenchment of European control." The Court declined to go further in specifying criteria, and no doubt this is an area open to much more interpretation depending on the particular claimant groups. Nevertheless, the Court has provided important guidance as to the interpretation of a word we could not define in 1982 .

These important strides in the jurisprudence since 1982 demonstrate what a bold initiative it was for governments to endorse section 35 because so much of the probable effect of this section was unknown. This was, in my view, one of the most important aspects of the 1982 Act because it gave formal constitutional recognition and protection to many Aboriginal rights, often asserted but seldom recognized without qualification. While governments were amply familiar with the legal means and consequences of patriation, and generally understood the nature and scope of the rights being entrenched in the Charter (most of these were already recognized in ordinary laws in one form or another), section 35 launched a novel exercise in the definition and protection of Aboriginal rights of which Euro-Canadian society, at least, had little understanding or acceptance. The fundamental purpose of section 35 was well stated by Chief 
Justice Lamer, in Van der Peet ${ }^{51}$ :

More specifically, what s. 35(1) does is provide the constitutional framework through which the fact that aboriginals lived on the land in distinctive societies, with their own practices, traditions and cultures, is acknowledged and reconciled with the sovereignty of the Crown. The substantive rights which fall within the provision must be defined in light of this purpose; the aboriginal rights recognised and affirmed by s. 35(1) must be directed towards the reconciliation of the preexistence of aboriginal societies with the sovereignty of the Crown.

The answer to the question of where this process would take Canada was undoubtedly the biggest unforeseeable we were to face in 1982.

\section{Conclusion}

By way of summary then of what was foreseen and unforeseen by the framers of the Constitution Act, 1982, I would first say that we correctly foresaw a patriated Constitution over which Canada would have complete legal control for purposes of amendment in the future. We correctly foresaw an effective Charter that would legally enhance the rights of Canadians, establish a human rights culture in Canada, and reinforce the growing pluralism of our society. We correctly saw important enhancements in, and new definitions of, Aboriginal rights which would contribute a new dimension to justice in our society.

Matters which we did not foresee included a continuing political controversy over patriation, and interpretations of the Charter which entailed greater judicial incursions into the legislative domain than were anticipated by the elected representatives of the people who agreed to the text of that document. As I have said, the framers could not foresee either the exact scope or effect of guaranteeing Aboriginal rights, but would not generally be surprised by the outcome.

I therefore remain convinced that the Constitution Act, 1982 was a measure of immense importance in the maturing of our nation. I can only hope that time will bring a fuller consen- sus on the fact of patriation and the meaning of the rights it has entrenched.

\section{Notes}

* Hon. Barry L. Strayer, Q.C., formerly Judge of the Federal Court of Appeal and Chief Justice of the Court Martial Appeal Court of Canada.

This article is based on a presentation delivered in Regina on 24 May 2007, at a "Living Tree" conference on the $25^{\text {th }}$ anniversary of the Constitution Act, 1982, organised by the Saskatchewan Institute of Public Policy, University of Regina.

1 Pierre Elliot Trudeau, A Canadian Charter of Human Rights (Position Paper) (Ottawa: Queen's Printer, 1968).

2 Being Schedule B to the Canada Act, 1982 (U.K.), 1982 , c. 11.

3 Part I of the Constitution Act, 1982 supra note 2 [Charter].

4 Paraphrase of Secretary of Defence Donald H. Rumsfeld, News Transcript, United States Office of the Assistant Secretary of Defence (Public Affairs), 12 February, 2002. The actual quotation is as follows: "[T] here are known knowns; there are things we know we know. We also know there are known unknowns; that is to say we know there are some things we do not know. But there are also unknown unknowns - the ones we don't know we don't know."

5 Constitution Act, 1867 (U.K.), 30 \& 31 Vict., c.3, reprinted in R.S.C. 1985, App. II , No. 5.

6 Commonwealth of Australia Constitution Act, 1900 (U.K.) 63\&64 Vict., c. 12, s. 128.

7 (U.K.), 22 \& 23 Geo. V, c. 4, s. 2.

8 Re: Resolution to Amend the Constitution [1981] 1 S.C.R. 753 (CanLII) [Patriation Reference].

9 Reference re Amendment of the Canadian Constitution [1982] 2 S.C.R. 793.

10 Supra note 8 at 886.

11 "Close to one third of Canadians unsure if new constitution good" Ottawa Citizen (19 June 1982) 4.

12 Kirk Makin, “Two Thirds Back Electing Judges: Twenty-Five Years Later, poll show strong support for Charter" Globe \& Mail (9 April 2007) A5.

13 (3 June 1987), online: The Canadian Encyclopedia $<$ http://www.thecanadianencyclopedia. com/index.cfm?PgNm=TCE\&Params=A1ARTA 0010100>.

14 Consensus Report on the Constitution (28 August 1992), online: The Canadian Encyclopedia 
$<$ http://www.thecanadianencyclopedia.com/index. $\mathrm{cfm}$ ?PgNm=TCE\&Params=A1ARTA0010099>.

House of Commons Debates, No. 086 (24 November 2006) at 5299 (Hon. Laurence Cannon).

G.A. res. 217A (III), U.N. Doc A/810 at 71 (1948) [Declaration].

17 See Christopher MacLennan, Toward the Charter: Canadians and the demand for a national bill of rights, 1929-1960 (Montreal: McGill-Queen's University, 2003) at 70-75; I have dealt with this history more extensively in Barry L. Strayer "In the Beginning ... the Origins of Section 15 of the Charter" (2006) 5 Journal of Law \& Equality 13 at $15-16$. S.C. 1960 , c. 44 , s. 2 , reprinted in R.S.C. 1985 , App. III. Charter, supra note 3, s. 15 [emphasis added]. Supra note 2, s. 52.

Supra note 3, s. 24. [1992] 2 S.C.R. 679 (CanLII) [Schachter]. In fact the Court found it unnecessary to "read in" to the impugned statute because Parliament had already amended the law consistently with the constitutional findings of the Trial Judge, who declared the existing structure contrary to $s$. 15 of the Charter but suspended judgment to allow Parliament to make the changes it thought fit to make the legislature conform. I was the Trial Judge: see Schachter v. Canada [1988] 3 F.C. 515. [1997] 3 S.C.R. 624.

See for example Auton v. Canada [2004] 3 S.C.R. 657 (CanLII); Canada v. Hislop [2007] S.C.J. No. 10.

[1998] 1 S.C.R. 493.

27 See also Haig v. Canada (1992), 9 O.R. (3d) 495 (O.C.A.) (CanLII).

C.Motor Vehicle Act [1985] 2 S.C.R. 486 (CanLII) [Motor Vehicle].

Supra note 3, s. 7.

Duke v. the Queen [1972] S.C.R. 917 at 923. (1610), 77 E.R. 646 at 652 (K.B.).

H.A.L. Fisher, ed., vol. 2 The Collected Papers of Frederic William Maitland (Cambridge: Cambridge University Press, 1911) at 481.

33 Supra note 28 at para. 16.

34 See the dictum of Viscount Sankey, L.C. in Edwards v. Attorney-General of Canada [1930] A.C. 124 at 136. [2005] 1 S.C.R. 791.

R.S.Q. c. C-12.

Supra note 2, s. 35.

Supra note 8.

[1973] S.C.R. 313.

[1997] 3 S.C.R. 1010 at para. 117 (CanLII).

Ibid. at para. 117-24.
42 See e.g. R. v. Van der Peet [1996] 2 S.C.R. 507 at para. 69-74 (CanLII) [Van der Peet]. For an insightful comparison between aboriginal title and other aboriginal rights see Brian Burke, "Left out in the Cold: the Problem with Aboriginal Title under section 35(1) of the Constitution Act, 1982 for Historical Nomadic Aboriginal Peoples" (2000) 38 Osgoode Hall Law Journal 1 at 1-17.

43 Supra note 3, s. 1.

44 See e.g. R. v. Sparrow [1990] 1 S.C.R. 1075 at para. 75-83 (CanLII) [Sparrow]; R. v. Gladstone [1996] 2 S.C.R. 723; Delgamuukw supra note 40 at para. 160-69.

45 Sparrow, ibid. at para. 73.

46 Supra note 40 at para. 170.

47 See for example Campbell v. Attorney General (British Columbia) 2000 B.C.S.C. 1123 at para. 81-82.

48 Supra note 5.

49 Reference re Eskimos [1939] S.C.R. 104. The very name of the case suggests a Eurocentric view of our aboriginal peoples: the northern dwellers called themselves the "Inuit."

50 [2003] 2 S.C.R. 207 (CanLII).

51 Supra note 42 at para. 31. 